Sirenko N. M., Doctor of Economic Sciences, Professor, the Head of the Department of Finance, Banking and Insurance, Mykolayiv National Agrarian University, Mykolayiv, Ukraine

ORCID ID: 0000-0003-1660-1073

e-mail: sirenko@mnau.edu.ua

Mikulak K. A., Assistant of the Department of Finance, Banking and Insurance, Mykolayiv National Agrarian University, Mykolayiv, Ukraine

ORCID ID: 0000-0001-8317-0360

e-mail: mikulyak@mnau.edu.ua

Ihnatenko Zh. V., Teacher of the Foreign Languages Department, Mykolayiv National Agrarian University, Mykolayiv, Ukraine

e-mail: ignatenko@mnau.edu.ua

\title{
Financial Mechanisms for the Development of the Agrarian Sector in Market Environment
}

Abstract. Introduction. The financial mechanisms of agrarian sector development, which are necessary in creating a solid financial basis for its functioning not only in domestic, but also in foreign markets, are considered. Expenditure fluctuations for the agrarian sector for the period of 2013-2018 are presented, the main expenditures on budget programs of the agro-industrial development, which include scientific research, financial support of agricultural producers, livestock support, financial support for the development of farms, and the costs of the Agrarian Fund are analyzed. The share of developed investments for the period of 2012-2018 and the indices of capital investments in agriculture, forestry and fish farming have been explored. The dynamics of direct investment (share capital) inflow into the economy of Ukraine depending on types of economic activity is shown and other financial mechanisms of development of the agrarian sector are reflected.

In present conditions, the strategy of developing agricultural enterprises is largely dependenon the ability to adapt to changing conditions of the external market environment and the sensitivity to introducing various types of innovations and achievements in scientific and technological progress. The active globalization processes that involve the formation of world commodity and financial markets and the integration of the national economy into the global economic system lead to a significant increase in the role of foreign economic relations, which increases their importance for the development of the agrarian sector of the economy, which largely depends on the proper participation of the state in its formation and sales.

Purpose. To analyze the theoretical and methodological principles of the agrarian sector financial regulation mechanism in the conditions of Ukraine's integration into the world economic space, thus strengthening the role of foreign economic relations.

Results. The financial mechanisms of the development of the agrarian sector, including instruments of fiscal, tax, customs, currency, pricing and investment policy in the form of incentives or restrictions are considered. The main expenses for the budget programs for the development of the agro-industrial complex were analyzed, and the largest share was also found in the structure of expenditures on budget programs for the development of the agricultural complex. The share of investments in January-June 2018 was investigated, and it was found that their relative index is $13.0 \%$ versus $16.1 \%$ of the same period last year. As of January-June 2018, 26.9 billion UAH were used in agriculture, forestry and fishing. The largest share in total investment in agriculture, forestry and fishing was in Kyiv (10.9\%), Vinnytsia (8.9\%), Dnipropetrovsk (6.8\%) and Mykolayiv (3.7\%). The Transcarpathian region was in last place with an index of $0.2 \%$.

Conclusions. For the purpose of effective development of the agrarian sector of the economy, it is necessary to take into account the specifics of agricultural production, to apply specialized regulation mechanisms to increase the profitability of agricultural enterprises, to increase state budget revenues and to ensure the competitiveness of agricultural products in the domestic and foreign markets with the support of small commodity producers and the creation of credit cooperatives, specialized agriculture, bank support for the sector, farm income stabilization, state guarantees for insurance payments, and futures instruments in support of rural development support programs.

Keywords: agrarian sector; agricultural receipts; agro-industrial complex; state budget expenditures; capital investments; lending; financial instruments; financial mechanism.

УдК 631.1.016: 330.11

Сіренко Н. М., д-р екон. наук, професор, завідувач кафедри фінансів, банківської справи та страхування, Миколаївський національний аграрний університет, м. Миколаїв, Україна 
Мікуляк К. А., асистент кафедри фінансів, банківської справи та страхування, Миколаївський національний аграрний університет, м. Миколаїв, Україна

Ігнатенко Ж. В., викладач кафедри іноземних мов, Миколаївський національний аграрний університет, м. Миколаїв, Україна

\section{Фінансові механізми розвитку аграрного сектора у ринковому середовищі}

Анотація. Розглянуто фінансові механізми розвитку аграрного сектора, які є необхідними для створення міцної фінансової основи не лише в середині країни, але і на зовнішніх ринках, до яких належать інструменти бюджетної, податкової, митної, грошово-кредитної, цінової та інвестиційної політики у формі стимулювання або обмеження. Наведено динаміку видатків на аграрний сектор за період 2013-2018 рр., проаналізовано основні видатки на бюджетні програми розвитку агропромислового комплексу, до яких належать наукові дослідження, фінансова підтримка сільськогосподарських товаровиробників, підтримка тваринництва, фінансова підтримка розвитку фермерських господарств, витрати Аграрного фонду. Досліджено частку освоєних інвестицій за період 2012-2018 рр. та індекси капітальних інвестицій у сільське, лісове та рибне господарство. Відображено динаміку надходження прямих інвестицій (акціонерного капіталу) в економіку України в залежності від видів економічної діяльності та відображено інші фінансові механізми розвитку аграрного сектора. Встановлено, що для забезпечення ефективного розвитку аграрного сектора економіки необхідно враховувати специфіку сільськогосподарського виробництва, застосовувати спеціалізований регулюючий механізм, з метою підвищення прибутковості сільськогосподарських підприємств, створювати кредитні кооперації та спеціал ізовані аграрні банківські установи, використовувати форвардні та ф'ючерсні інструменти на аграрному ринку. Доведено, що для досягнення максимального стимулюючого ефекту розвитку аграрного сектора необхідна комплексна та ефективна взаємодія усіх складових механізму фінансового регулювання, що передбачає поєднання внутрішніх джерел фінансування та наявних ресурсів фінансово-кредитних установ, що за належної державної підтримки розвитку інфраструктури фінансово-кредитного забезпечення виробництва дозволить створити міцну фінансову основу функціонування аграрного сектора економіки України.

Ключові слова: аграрний сектор; аграрні розписки; агропромисловий комплекс; видатки державного бюджету; капітальні інвестиції; кредитування; фінансові інструменти; фінансовий механізм.

Problem statement. Under the current conditions, the strategy of developing agricultural enterprises largely depends on the ability to adapt to the changing conditions of the external market environment and the susceptibility to introducing various types of innovations and achievements of scientific and technological progress. Active globalization processes, which involve the formation of world commodity and financial markets and the integration of the national economy into the global economic system, lead to a significant increase in the role of foreign economic relations, which increases their importance for the development of the agrarian sector of the economy, which largely depends on the proper participation of the state in its formation and sales.

Due to limited budget resources and the necessity of ensuring the mechanism of state regulation of economic processes at the proper level, which is realized through methods of administrative, legal and financial and economic influence [3] become increasingly important. A decisive role in the state regulation of economic processes is taken by the methods of financial regulation, which involve the use of instruments of budgetary, monetary and investment policy. Therefore, the study of financial mechanisms for the development of the agrarian sector of the economy is of particular importance, given the limited financial resources of agricultural enterprises, the rapid escalation of socio-economic problems due to political and economic instability, and adaptation to the conditions of functioning in the external market environment.
Analysis of recent research and publications. It has been researched the theoretical and methodological principles of state regulation of the economy to provide financial resources for the development of the agrarian sector in today's conditions is being paid a lot of attention by domestic scientists, among which are: M. Baschenko [11], Yu. Lupenko [3], Ya. Mandzalo [11], N. Tanklevskaya [7] et al.

In Ukraine, the issues of long-term development of the industry are presented in the Strategic Directions of development of the agrarian sector of the economy till 2020 [10], a document developed at the National Research Center "Institute of Agrarian Economics", on the basis of which the relevant Strategy was approved by the Cabinet of Ministers of Ukraine [9]. A more modern and comprehensive document - Strategy for the development of agricultural production in Ukraine for the period up to 2025 - was worked out by the institutions of the National Academy of Agrarian Sciences of Ukraine [11].

Formulation of research objectives. The purpose of the study is an analysis of theoretical and methodical principles of activating the mechanism of financial regulation of the agrarian sector in the conditions of Ukraine's integration into the world economic space, thus strengthening the role of foreign economic relations.

Presentation of the main research material. An important factor in the success of a financial policy of a particular industry or specific region is their compliance with internal and external capabilities. On the basis of data on financial potential, one can get complete 
information on the totality of available and prospective financial resources. Using data on the available financial potential, it is possible to determine the optimal variant of the development of financial relations and to form an optimal financial policy. Knowledge of the level, quality, and dynamics of financial potential can reveal internal reserves, a wider use of financial incentives, and provide a closer relationship between the planned development indicators and real opportunities for their implementation [6].

It should be noted that the existing financial mechanism for managing the development of the economy does not meet the international standards of financial regulation and requires appropriate improvement. The main negative feature of this mechanism is the financial impact through direct budget financing or subsidies from the budget to specific economic entities. In addition, the use of these budget tools is unsystematic and selective, and the selective approach in financial support is furthermore not based on scientifically sound criteria and the indicators that determine them [2].

Increasing the efficiency of agricultural development and foreign economic activity of the agrarian enterprises of Ukraine is a strategic task of the state policy in the context of the national economy into the global economic system.

The most general model for the development of the agrarian sector justified in 2017 at the NNC "IAE" became the paradigm for a strategic vision of the agrarian system of Ukraine, which is aimed at ensuring the integrated development of agriculture and rural areas under decentralization, European integration, and the introduction of market circulation of agricultural land [1]. This model includes a strategic vision of multifunctional agriculture, optimization of land tenure and land use, organization of agricultural activities and the development of integration processes on the basis of multidisciplinarity, the placement of productive forces of agriculture in rural areas, and a strategy for its development using the territorially integrated approach of the EU [1].

Authors agree with the opinion of Yu. O. Lupenko [3] that the main mechanisms for the implementation of this model:

1) creation of favorable economic conditions for agricultural production for all organizational and legal forms of management;

2) formation of conditions for raising the level of employment, wages, and incomes of rural population, and introducing codes of independent agricultural practice;

3) development and implementation of state economic, regional target, and local programs for the complex development of agriculture and rural territories;

4) a rational combination of sectoral and territoriallyself-governing control systems on the basis of an EU- territorially-integrated approach adapted to the conditions of Ukraine;

5) assistance in the development of the system of public and inter-farm self-government in the agroindustrial complex;

6) development of public-private partnership;

7) creation of conditions for efficient functioning of the agricultural products and food market;

8) development of the system of technical, technological, investment, personnel, scientific and innovative, informational and consulting support of agricultural activity;

9) application of budgetary and other state support to large agricultural producers and small farmers [3].

The state budget in 2017 was the impetus for a new state support to the agrarian sector, which limited the effect of indirect funding and regulated the annual amount from the State Budget to support agricultural producers to at least $1 \%$ in agricultural production for the period from 2017 to 2021. The level of agrarian production in 2015 and the amount of budget resources totaled UAH 5.5 billion.

The Ukrainian law "On the State Budget of Ukraine for 2018" (with amendments) provides the Ministry of Agrarian Policy with a budget in the amount of UAH 12 456.1 million, of which the amount allocated to the development of agro-industrial complex was UAH 6311.0 million, including:

-2801030 "Financial support measures in the agroindustrial complex by reducing the cost of loans" -66.0 million UAH;

-2801230 "Financial support for the development of farms" - 1000,0 million UAH;

-2801350 "State support for the development, installation and supervision of young gardens, vineyards and berries" - 300.0 million UAH;

-2801540 "State support of the livestock sector" 2300,0 million UAH;

-2801580 "Financial support of agricultural producers" - 2,945.0 million UAH [2].

The volume of state support for the agrarian sector for the period 2013-2018 is shown in Figure 1.

An analysis of data in Fig. 1 shows that the smallest amount of expenditures on the agrarian sector was in 2016, which in absolute terms amounted to UAH 2.171 billion. In 2017, the amount of state support was UAH 9.572 billion, which is UAH 2.884 billion less than the planned expenditure amount in 2018. The volume of lending to the agrarian sector began to increase in 2017 to UAH 0.842 billion, which is more than the previous year's survey of UAH 0.755 billion. In 2018, the amount of financing is planned at the amount of 0.941 billion UAH, which is UAH 0.099 billion more than in 2017. The given situation shows that the support of the agrarian sector by the state during the investigated period is increasing. 


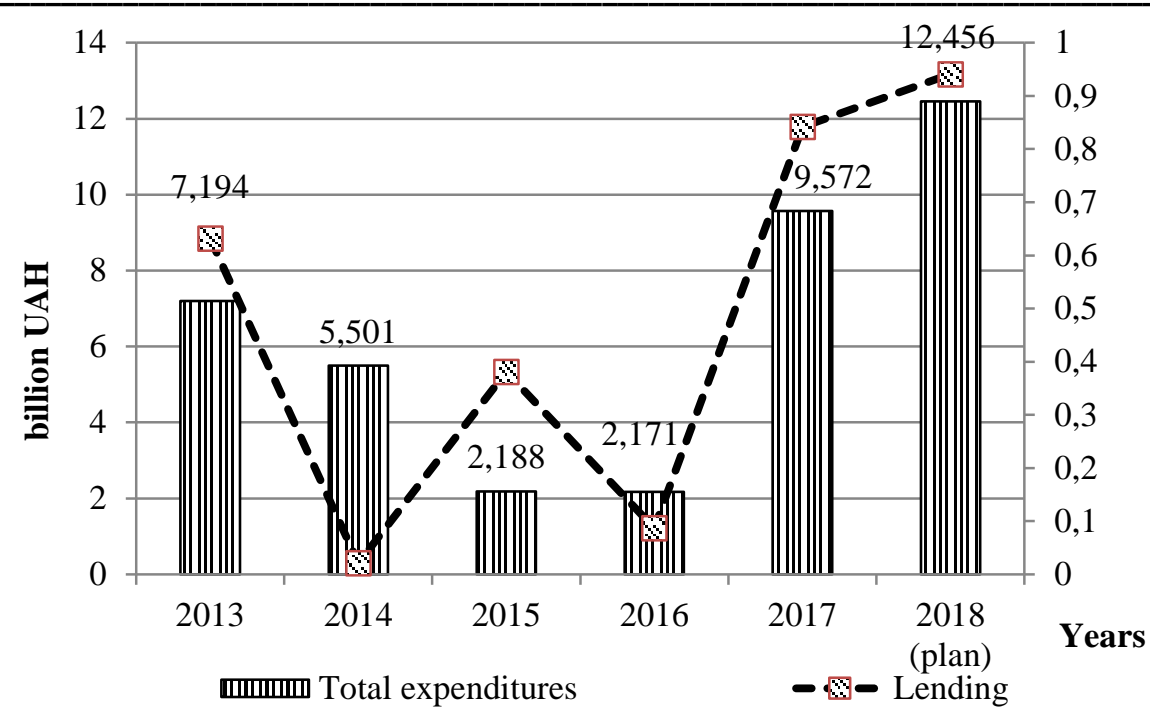

Figure 1 - Dynamics of expenditures in the agrarian sector of the economy of Ukraine for 2013-2018, UAH billions

Source: Data-based [2]

One method of financial regulation, which involves the use of a budgetary tools policy, is through the budget programs for the development of the agro-industrial complex in 2017-2018, presented in Fig. 2.

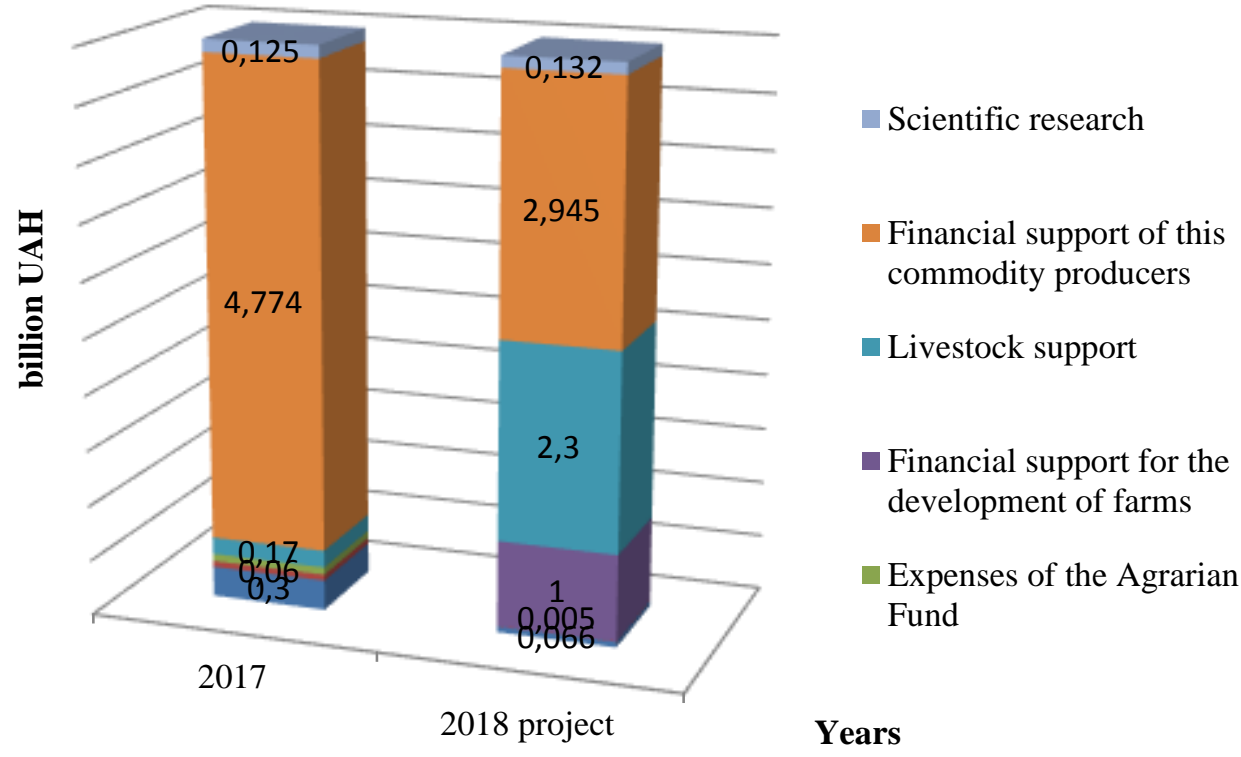

Figure 2 - Expenditures on budget programs for the development of the agrarian and industrial complex in 2017-2018, in billions of UAH

Source: built on the basis of data [2]

Analysis of the data shows that the largest share in the structure of expenditures on budgetary programs for the development of the agro-industrial complex in 2018 provides financial support for agricultural producers, which in absolute terms amounts to 2.945 billion UAH (or $45 \%$ ), of which 2.0 billion UAH (or 70\%) is directed to subsidies, while another 0.945 billion UAH falls on cheaper domestic agricultural machinery. 2.3 billion UAH is spent on livestock support, namely, partial reimbursement of costs: purchased for future reproduction of heifers, milk cows and milk and meat production; construction and reconstruction of livestock farms and complexes, as well as cheaper interest on loans. The financial support for the development of farms in absolute terms is 1 billion UAH (or $15 \%$ ). We agree with the conclusions of domestic scientists that the development of farms as 
representatives of small and medium enterprises is one of the main objective indicators of the real investment climate in agriculture [3, p. 44], although the organic peculiarity of agriculture has the risk of a shortage of finished products in the expected volume due to circumstances unrelated to the producer (i.e. unfavorable climatic conditions or animal disease [3]). Experts prove that, as of now, the priority remains for investing in agriculture over the food industry [6]. Therefore, in the nearest future, there exists an acute opportunity to take advantage of this investment attractiveness in the agricultural market to improve the competitiveness of farms.

Another financial instrument geared towards supporting the agrarian sector is the capital investment in agriculture, forestry, and fisheries, as shown in Fig. 3.

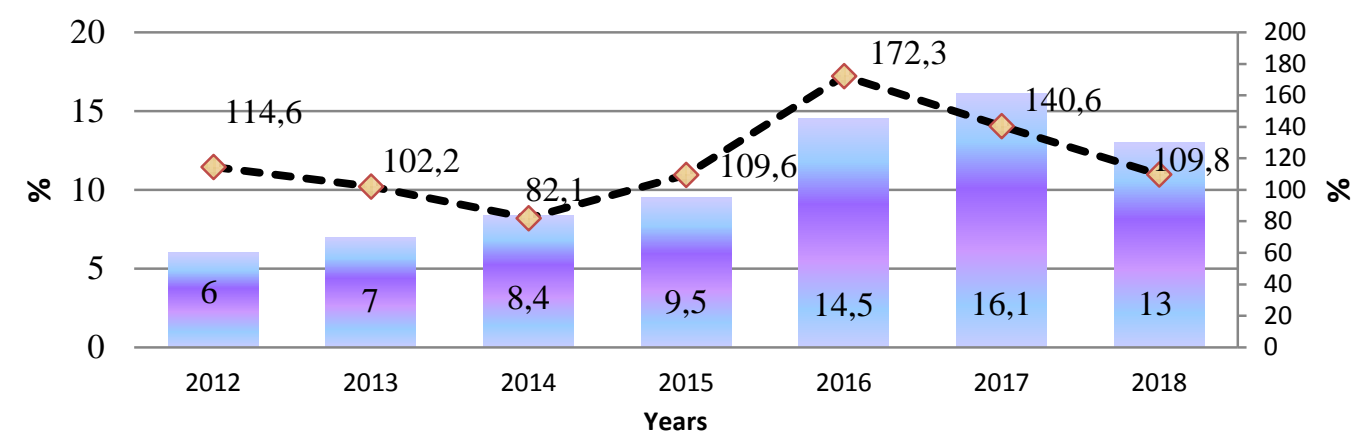

Share of the developed investments in the total volume for January-June of the corresponding year, \%

$\leadsto-$ Capital investment indices for January-June of the corresponding year, to the corresponding period of the previous year, $\%$

Figure 3 - Capital investment in agriculture, forestry, and fisheries in January-June 2012-2018, \%

\section{Source: based on data [2]}

The share of capital investment in January-June 2018 is $13.0 \%$ against $16.1 \%$ during the same period of the previous year. As of January-June 2018, 26.9 billion UAH of investments were used in agriculture, forestry, and fisheries. The largest share in the total amount of investments in agriculture, forestry, and fisheries in Ukrainian areas is: Kyiv (10.9\% - 1st place), Vinnitsa (8.9\% - 2nd place), Dnipropetrovsk (6.8\% - 3d place), Mykolaiv Oblast is ranked in the 14th place (3.7\%). Last place is the Transcarpathian region with the index of $0.2 \%$.

Since 2017, the agrarian sector of the economy has begun to use no special regime for VAT refunds, but $1 \%$ of GDP, which is in the form of "live" money, is UAH 6.3 billion (in 2017 - UAH 5.5 billion). In 2018, the budget support (subsidy) provides UAH 6.3 billion, which is UAH 0.8 billion more than in 2017. Another relatively new, convenient, and easy mechanism for financing the agrarian sector is the agricultural receipts that appeared in Ukraine in 2014. During the period of their implementation, 154 agrarian receipts were signed, with the help of which farmers received almost UAH 1.08 billion of additional money. The largest number of agrarian receipts was signed in 2018 in the Vinnitsa and Poltava regions -41 , Cherkassy region - 33, Kharkiv region - 22, Ternopil region - 12, Sumy and Khmelnytskyy regions - 7, and Mykolayiv region - 2. Today in Ukraine there are two main types of agrarian receipts: commodity and financial. The recent ones are the biggest - 100, but 65 agricultural agrarian receipts used a large sum of money 600 million UAH [2].

Important financial support for the agrarian sector is not only internal financial assistance, but also external, which comes in the form of direct investment (equity). The biggest amount of foreign direct investment for 07.01.2018 was aimed at industry - 10,910,400,000 US dollars, real estate transactions - \$ 3911.7 million USD, \$ 580.3 million were for rural, forestry, and fisheries, which is more than $\$ 1.7$ million US for the beginning of the reporting year. Financial leasing remains an important element of financing the agrarian sector. According to the National Commission, which regulates financial services markets, agriculture and transport remain leaders in attracting finance through leasing operations. By August 30,2018 , the value of financial leasing contracts amounted to UAH 6.5 billion in agriculture, and its share in total leasing operations was $27 \%$ [5].

Conclusions and perspectives of further research. According to the results of a study on financial mechanisms for the development of the agrarian sector in the market environment, the following conclusions were drawn:

1. The financial mechanisms for the development of the agrarian sector, which include instruments of fiscal, monetary and investment policy in the form of incentives or restrictions, are considered.

2. The dynamics of expenditures for the agrarian sector is indicated, and it is established that in 2013 they 
amounted to 7,194 billion UAH. The planned amount of financing for 2018 is UAH 0,941 billion, which is UAH 0.099 billion more than it was in 2017.

3. The main expenditures in the budget programs of the agro-industrial complex were analyzed, and it was found that the largest share in the structure of expenditures for budget programs for the development of the agro-industrial complex in 2018 is financial support of agricultural producers, which in absolute terms makes UAH 2.945 billion (or 45\%), of which 2.0 billion UAH (or $70 \%$ ) is aimed at subsidies, while another 0.945 billion UAH falls on cheaper domestic agricultural machinery. 2.3 billion UAH is spent on livestock support. The financial support for the development of farms in absolute terms is 1 billion UAH (or 15\%), which is used to improve the competitiveness of farms.

4. The share of developed investments in January-June 2018 was investigated, and it was determined that its relative expression is $13.0 \%$ against $16.1 \%$ over the same period of the previous year. In January-June 2018, 26.9 billion UAH of investments were used in agriculture, forestry, and fisheries. The largest share in the total volume of investments in agriculture, forestry, and fisheries in the region is taken by Kyiv - 10.9\%, Vinnitsa 8.9\%, Dnipropetrovsk - $6.8 \%$, Mykolaiv - by $3.7 \%$.

5 . On the basis of shown direct investments, it was found that 580.3 million US dollars were allocated to agriculture, forestry, and fisheries, which is more than \$1.7 million US dollars for the beginning of the reporting year.
6. In order to ensure the effective development of the agrarian sector of the economy, taking into account the specifics of agricultural production, we consider it is necessary to apply a specialized regulatory mechanism in order to increase the profitability of agricultural enterprises and ensure the competitiveness of agrarian products in domestic and foreign markets; create credit cooperatives and specialized agrarian banking institutions; provide state guarantees of insurance indemnity; develop forward and futures instruments in the agrarian market and rural development support programs.

In 2017 the National Scientific Center "Institute of Agrarian Economics" formed a system of organizational and economic models, the realization of which in practice would accelerate the economic development of the agrarian sector of the economy and rural areas, primarily due to the synergetic effect of progressive changes in most of the key areas of this development.

In our opinion, in order to achieve the maximum stimulating effect, all components of the financial regulation mechanism of the agrarian sector of the Ukrainian economy should be comprehensively and effectively integrated, which would involve a combination of internal sources of financing with available resources of financial and credit institutions. With proper state support for the development of the infrastructure of financial and credit provision of production, it is possible to create a solid financial basis for the functioning of the agrarian sector of the Ukrainian economy.

\section{References:}

1. Lupenko, Yu. O. \& Kropyvko, M. F. (Eds.) (2017). Ahrarnyi ustrii Ukrainy [Agrarian system of Ukraine]. Kyiv: NNTs IAE [in Ukrainian]

2. Ministry of Agrarian Policy and Food of Ukraine (2018). Retrieved from https://clck.ru/EeaXu [in Ukrainian].

3. Lupenko, Yu. O. (2007). System transformations of the agrarian sector of the economy. Ekonomika APK, 5, 49-51 [in Ukrainian].

4. Ministry of Agrarian Policy and Food of Ukraine (2018). The ranking of the regions for the production of agricultural products. Retrieved from https://clck.ru/EeTT8 [in Ukrainian].

5. State Statistics Service of Ukraine (2018). Retrieved from http://www.ukrstat.gov.ua. [in Ukrainian].

6. Sirenko, N. M. \& Melnyk, O. I. (2013). Fiscal stimulation of innovation development of the agricultural sector. Economist, 4, 28-32 [in Ukrainian].

7. Tanklevska, N. S. (2010). Modern trends in the development of credit policy in the agrarian sector of the economy. Naukovyj visnyk NUBiP, 145, 387-395.

8. Yaroshchuk, A. (2018). The financial "seven" - the main ways to get funds for the development of the agricultural business. Retrieved from https://clck.ru/Eeaed.

9. Cabinet of Ministers of Ukraine (2013). Pro skhvalennia Stratehii rozvytku ahrarnoho sektoru ekonomiky na period do 2020 roku [On approval of Strategy for a development of the agrarian sector of economy up to 2020], Rozporiadzhennia Kabinetu Ministriv Ukrainy vid 17.10.2013 № 806-r [Order No. 806-r, October, 17]. Retrieved from http://zakon.rada.gov.ua/laws/show/806-2013-p. [in Ukrainian].

10. Lupenko, Yu. O. \& Mesel-Veseliak, V. Ya. (Eds.) (2012). Stratehichni napriamy rozvytku silskoho hospodarstva Ukrainy na period do 2020 roku [Strategic directions of development of agriculture of Ukraine for the period up to 2020]. Retrieved from https://issuu.com/nnc_iae/docs/strateg_zbirnyk_zmist [in Ukrainian].

11. Hadzalo, Ya. M., Bashchenko, M. I., Zhuk, V. M. \& Lupenko, Yu. O. (Eds.) (2016). Stratehiia rozvytku silskohospodarskoho vyrobnytstva v Ukraini na period do 2025 roku [Strategy of development of agricultural production in Ukraine up to 2025], Kyiv: Ahrarna nauka [in Ukrainian]. 